\title{
Socioeconomic diversities and infant development at 6 to 9 months in a poverty area of São Paulo, Brazil
}

\author{
Diversidades socioeconômicas e o desenvolvimento infantil de 6 a 9 meses no \\ estado de São Paulo, Brasil
}

\author{
Patricia Tella, ${ }^{1,2}$ Luciane da Rosa Piccolo, ${ }^{3}$ Mayra Lemus Rangel, ${ }^{3}$ Luis Augusto Rohde, ${ }^{2,4}$ \\ Guilherme Vanoni Polanczyk, ${ }^{2,5}$ Euripides Constantino Miguel, ${ }^{2,5}$ Sandra Josefina Ferraz Ellero Grisi, ${ }^{1,2}$ \\ Bacy Fleitlich-Bilyk, ${ }^{2,5}$ Alexandre Archanjo Ferraro ${ }^{1,2}$
}

\begin{abstract}
Introduction: The effects of socioeconomic disparities on cognitive development tend to emerge early in infancy and to widen throughout childhood, and may perpetuate later in life. Although the study of how poverty affects early childhood has increased in the last 20 years, many of the effects remain largely unknown, especially during the first year of life.

Aim: To investigate the influence of socioeconomic status (SES) and maternal education on infants' language, motor and cognitive development.

Methods: The cognitive, language and motor skills of 444 infants aged 6 to 9 months selected from a poor neighborhood in São Paulo, Brazil, were evaluated using the Bayley Scales of Infant Development. A questionnaire on socioeconomic background was administered to the participants' families.

Results: A positive association was found between SES and infants' performance on language and motor scales. Additionally, higher maternal education was associated with higher language and cognitive scores.

Conclusion: Our findings indicate that SES effects are detectable very early in infancy. This result has implications for the timing of both screening and intervention efforts to help children overcome the consequences of living in poverty.
\end{abstract}

Keywords: Development, Bayley, infants, risk factors, socioeconomic status, maternal education.

\section{Resumo}

Introdução: Os efeitos das disparidades socioeconômicas no desenvolvimento cognitivo tendem a surgir no início da primeira infância e a se ampliar ao longo da infância, e podem perpetuar-se mais tardiamente. Embora estudos mostrando os efeitos deletérios de um menor nível socioeconômico (NSE) no desenvolvimento na primeira infância tenham aumentado nos últimos 20 anos, muitos desses efeitos ainda permanecem desconhecidos, especialmente durante o primeiro ano de vida.

Objetivo: Investigar a influência do NSE e da escolaridade materna no desenvolvimento linguístico, motor e cognitivo do bebê.

Método: Foram avaliadas as habilidades cognitivas, linguísticas e motoras de 444 lactentes com 6 a 9 meses de idade selecionados em um bairro de baixo NSE na zona oeste de São Paulo, Brasil, utilizando-se as Escalas Bayley de Desenvolvimento Infantil. Um questionário também foi administrado para coletar dados sobre o background socioeconômico das famílias das crianças participantes. Resultado: Foi observada uma associação positiva entre NSE e o desempenho dos lactentes nas escalas de linguagem e desenvolvimento motor. Adicionalmente, maior educação materna esteve associada a escores mais altos nas escalas de desenvolvimento linguístico e cognitivo.

Conclusão: Os resultados deste estudo indicam que os efeitos do NSE são detectáveis muito cedo na primeira infância. Este resultado tem implicações para o timing de avaliações e intervenções que possam ajudar as crianças a superar as consequências de viver na pobreza.

Descritores: Desenvolvimento, Bayley, lactentes, fatores de risco, nível socioeconômico, escolaridade materna.

\footnotetext{
${ }^{1}$ Departamento de Pediatria, Faculdade de Medicina, Universidade de São Paulo, São Paulo, SP, Brazil. ${ }^{2}$ Instituto Nacional de Psiquiatria do Desenvolvimento para Crianças e Adolescentes, São Paulo, SP, Brazil. ${ }^{3}$ Teachers College, Columbia University in the City of New York, New York, NY, USA. ${ }^{4}$ Psiquiatria da Infância e Adolescência, Hospital de Clínicas de Porto Alegre (HCPA), Universidade Federal do Rio Grande do Sul (UFRGS), Porto Alegre, RS, Brazil. ${ }^{5}$ Departamento e Instituto de Psiquiatria, USP, São Paulo, SP, Brazil.

This study is part of the first author's dissertation entitled "Neurodevelopment assessment in a birth cohort, the delay rate at 6 months and the association with psychosocial and environmental factors," presented in December 2015 at Universidade de São Paulo, São Paulo, SP, Brazil. Submitted Jan 23 2017, accepted for publication Jan 082018.

Suggested citation: Tella P, Piccolo LR, Rangel ML, Rohde LA, Polanczyk GV, Miguel EC, et al. Socioeconomic diversities and infant development at 6 to 9 months in a poverty area of São Paulo, Brazil. Trends Psychiatry Psychother. 2018;40(3):232-240. http://dx.doi.org/10.1590/2237-6089-2017-0008
} 


\section{Introduction}

In the early years of a child's life, the care and stimulation provided by the family are essential for their growth and development. Approximately 35\% of children worldwide do not develop age-expected skills appropriately, and for children living in poverty, this percentage rises to $46 \%$. These findings represent a human and social inequity gap that tends to widen throughout childhood and adolescence. ${ }^{1}$

Environmental conditions, such as the levels of cognitive stimulation in the home, the family's routine, and cultural, educational and socioeconomic status (SES) may affect child development. Among psychosocial factors, poverty and related problems (such as low parental education, poor nutrition and poor housing conditions) have a negative influence on child development and are more frequent in lowincome populations. ${ }^{2-8}$ These negative factors affect the development of about $10 \%$ of children in Brazil. ${ }^{9-11}$ Parental education and occupation, family income, nutritional status and housing conditions, among other factors, may limit the provision of material and social resources for children, which in turn impacts their overall development. ${ }^{12-18}$ As such, the influence of income on material resources that can provide intellectually stimulating activities such as toys and books may contribute to child development. ${ }^{19}$

When family dysfunction occurs during sensitive stages of child development, the effects are even more pronounced. ${ }^{17}$ Some researchers suggest that children exposed to resource-poor environments can benefit from the skills they developed to survive in the midst of a vulnerable condition, and that this can protect them against future environmental adversities, regardless of the amount of deprivations early on. ${ }^{20}$ However, there is a large body of evidence showing that children exposed to environmental risk factors often have a history of poor adaptation and development skills. ${ }^{21}$ Even though individual differences in child development are strongly influenced by genetic processes, environmental factors such as education, health care, nutrition, and caregiving can significantly improve or damage developmental outcomes for children. ${ }^{6,22-25}$ In this sense, although it is indubitable that children develop skills in order to adapt to live in adverse environments, there is a consensus that living in poverty during the early years of life can negatively impact the child's development as early as in the first few months after they are born, ${ }^{8,26-28}$ and that this impact can extend into adulthood. ${ }^{29,30}$

The acquisition of essential skills during early development such as head and trunk control, crawling and walking are indicators of favorable growth when they occur within the expected time period. Furthermore, the development of higher cortical functions, namely language acquisition, not only demonstrates a satisfactory maturational process, but is also indicative of social, intellectual, and communicative achievements that are highly complex. ${ }^{31}$ If these basic skills are not met, they can be indicative of an abnormal language developmental trajectory. Deficits in the above mentioned areas can be related to factors such as SES, parenting practices, cognitive stimulation, and the quality of the child's linguistic environment. ${ }^{27,28,32-40}$

It is known that exposure to a language environment at home, especially at early ages, promotes the development of language in general (both oral and written). ${ }^{32,33,41}$ More educated parents tend to read more to their children, and support and assist their education. ${ }^{27,42}$ The education of family members, specifically of the mothers, is related to the best use of income with regard to child care and public services to the family. Education significantly contributes to the improvement of family income and living conditions, and health of the general population. ${ }^{43}$

Although an increasing number of studies has investigated the impact of SES on child neurocognitive development in the last 20 years, $8,28,44,45$ the precise mechanisms through which poverty affects early childhood are still largely unknown. Population-based studies in this field involving infants are rarer, even in development countries. ${ }^{46,47}$ Nevertheless, understanding how early in life the effects of environmental factors can be detected on infant development is critical so that more appropriate interventions can be planned. In this regard, the aim of this study was to investigate the influence of SES and maternal education on cognitive, language and motor development in children aged 6 to 9 months in a birth cohort selected from a poor neighborhood in the west region of the city of São Paulo, Brazil.

\section{Methods}

\section{Participants}

This is a cross-sectional investigation nested in a birth cohort from São Paulo, Brazil. The sample comprised children born from women who attended primary health facilities in the west region of the city of São Paulo, Brazil. This is a deprived area in the outskirts of a big metropolis.

We estimated our sample size supposing a language mean score of 105 in the high maternal education level and 95 in the low maternal education level, a standard deviation of 20 , a probability of type 1 error of $5 \%$ and a $90 \%$ statistical power. Based on this calculation, we would 
need 85 infants in each stratum of maternal education. Sample size calculation was made according to another study in which it occurs. ${ }^{48}$ Considering a probability of alpha error of $5 \%$, a prevalence of developmental delay at 12 months of $34 \%$ and an odds ratio of 4.0 in association with developmental delay, ${ }^{49} 270$ cases would be needed to reach a statistical power of $90 \%$. Considering $20 \%$ of loss during follow-up, 324 cases would be needed.

For this study, 444 infants between 6 and 9 months of age were evaluated, and $52.48 \%$ of them were female. Participants were not included in the study if they were born with any congenital syndrome associated with developmental impairment. Twins were also excluded.

\section{Instruments and procedures}

This study was approved by the ethics committee of Universidade de São Paulo, São Paulo, Brazil (protocol 0054/09). ${ }^{50}$ Infants were assessed only if their parents or guardians had signed the informed consent form. Data were collected by trained psychologists who were able to implement the instruments used. The families were contacted and the evaluations were carried out at the participant's houses.

The children were assessed using the Bayley Scales of Infant Development - third edition (Bailey III) ${ }^{51}$ in one session, lasting approximately 120 minutes, at the neighborhood's health care center. Language (expressive - such as object and picture identification - and receptive pre-verbal communication - such as babbling, gesturing, joint referencing and turn taking), motor skills (fine and gross motor skills) and cognition (sensorimotor development, exploration and manipulation, object relatedness, concept formation and memory) were assessed.

Bayley III is among the best existing tools for the assessment of child development: it is considered the gold standard by several authors and is largely used in child development studies. ${ }^{52}$ It allows a complete and detailed assessment of neurodevelopment, both for the general population and to evaluate risk groups (premature babies, for example), as well as for the evaluation of specific developmental disorders such as autism. Bayley III adjusts the age of the child according to gestational age. The first edition of Bayley scales was reviewed in 1969, in 1993 (Bayley Scales II) and in 2006 (Bayley Scales III) in the United States. The scales are an appropriate tool for assessing children with and without disabilities. A Brazilian version has been validated. ${ }^{53}$ The classification of child development according to the Bayley scales is based on composite scores. Child development can be classified as: 1) extremely low (score $\leq 69)$; 2) borderline (70-79); 3) low average $(80-89)$; 4) average $(90-109)$; 5) high average (110-119); 6) superior (120-129); and 7) very superior ( $\geq 130$ ).

SES was evaluated using the Brazilian Economic Classification Criteria proposed by the Brazilian Association of Research Companies (Associação Brasileira de Empresas de Pesquisa - ABEP), ${ }^{54}$ which combine parental education and the existence of household goods (as an estimation of purchasing power). This index provides a SES classification based on five levels: A, B, C, $D$, and $E$ ( $A$ is the higher level and $E$ the lowest). Families in the $A / B$ and $D / E$ SES levels had similar characteristics in this study. Thus, they were combined into the same SES status. Paternal occupation was based on the International Standard Classification of Occupations (ISCO) and classified as non-manual, qualified, semiqualified and unskilled manual. ${ }^{48,55}$

\section{Statistical analysis}

Given the skewed distribution of the outcome variables, results were presented as histograms, and their medians and interquartile ranges were described. Categorical variables were described as frequencies in \% and their respective $95 \%$ confidence intervals. Children's cognitive, language and motor development as assessed by Bayley III was compared based on paternal occupation, maternal education and family SES using bootstrapping quantile regression models. The null hypothesis was rejected when the probability on an alpha error was $\leq 5 \%$. Data analysis was conducted using the STATA software.

\section{Results}

\section{Descriptive analysis}

Bayley's measures of cognitive, language and motor development of the 444 infants were analyzed. The median scores (interquartile ranges) obtained were as follows: motor development $=97$ (88-107); language development $=100(91-106)$; and cognitive development $=100(95-110)$. These results are shown on Figures 1, 2 and 3.

Table 1 shows the development results found in each area, i.e., motor, cognitive and language. Major index delays in the development of infants were observed in motor $(9.32 \%)$ and language $(6.36 \%)$ skills. Most of the infants were classified as having medium development: $51.06 \%$ of infants in the motor area, $58.47 \%$ and $63.77 \%$ in language and cognition, respectively.

As can be seen in Table 2, most of the mothers had $\geq 11$ years of education (40.8\%). Families belonged mainly to "C" level (67.38\%) or medium SES. Among these mothers, $23.9 \%$ were adolescents ( $\leq 18$ years of age) and $56.56 \%$ were born in São Paulo. 


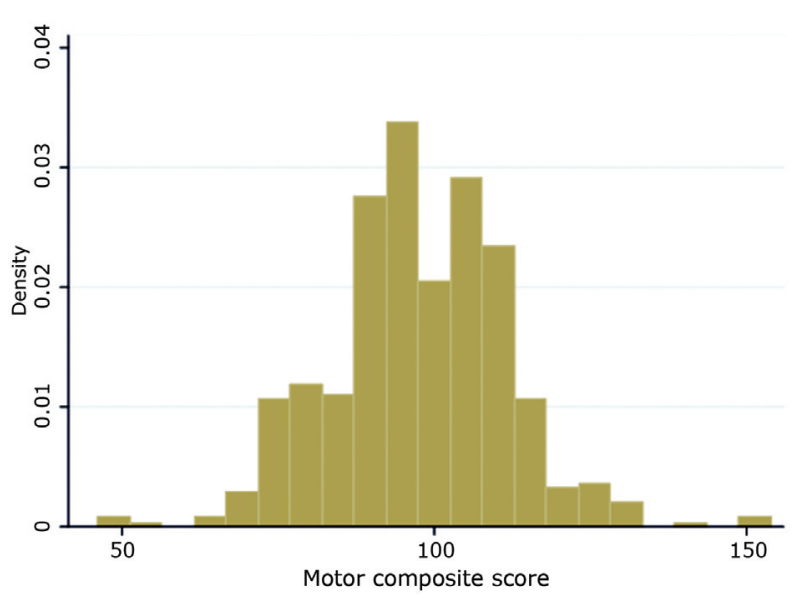

Figure 1 - Distribution of motor development composite scores according to Bayley III in infants aged 6 to 9 months.

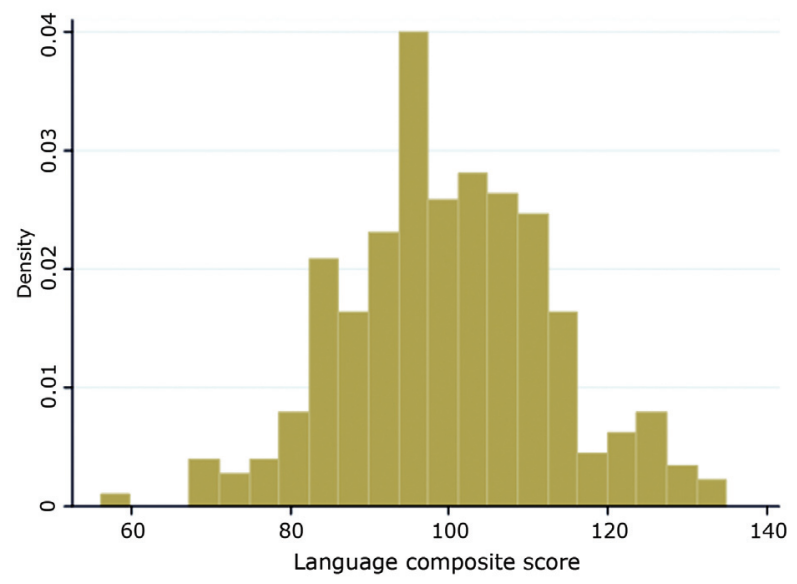

Figure 2 - Distribution of language development composite scores according to Bayley III in infants aged 6 to 9 months.

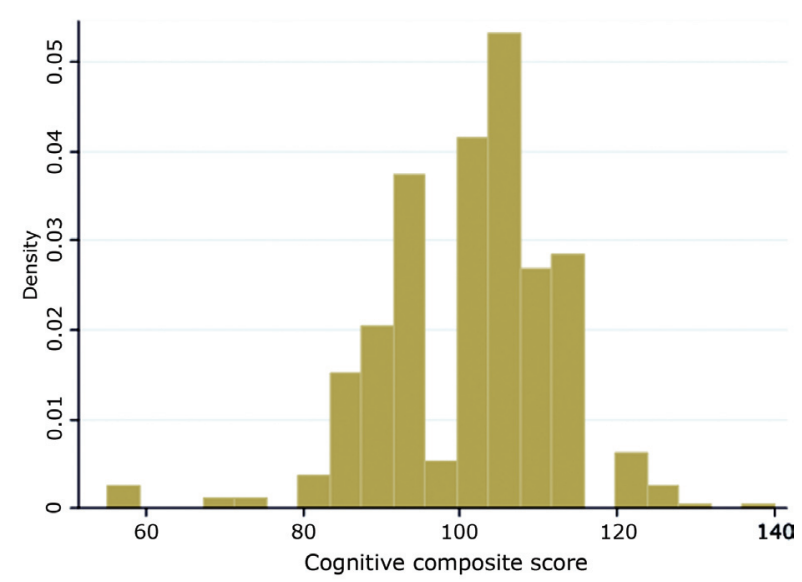

Figure 3 - Distribution of cognitive development composite scores according to Bayley III in infants aged 6 to 9 months.

\section{Associations between language, motor and cognitive performance and SES measures}

Table 3 shows that SES was positively associated with language and motor performance. Also, fewer years of maternal education were associated with lower language and cognitive scores. We did not find a direct association between parental occupation and infant development.

Sociodemographic variables were treated as continuous variables; effect size represents the effect caused by moving one stratum of the independent variable towards a less privileged situation.

\section{Discussion}

This study evaluated the development of infants at 6 to 9 months of age using the Bayley III scales in a Brazilian sample and estimated the influence of SES, maternal education and paternal occupation on the infants' development. Children from high SES levels showed better performance in language and motor tasks, and more years of maternal education were

Table 1 - Composite score of development according to Bayley III in infants aged 6-9 months, São Paulo, 2014

\begin{tabular}{|c|c|c|c|}
\hline & $\mathbf{N}$ & $\%$ & \% accumulated \\
\hline \multicolumn{4}{|l|}{ Motor } \\
\hline Extreme low & 6 & 1.3 & 1.3 \\
\hline Borderline & 44 & 9.3 & 10.6 \\
\hline Low average & 74 & 15.7 & 26.3 \\
\hline Average & 241 & 51.1 & 77.3 \\
\hline High average & 82 & 17.4 & 94.7 \\
\hline Superior & 17 & 3.6 & 98.3 \\
\hline Very superior & 8 & 1.7 & 100.0 \\
\hline \multicolumn{4}{|l|}{ Language } \\
\hline Extreme low & 5 & 1.06 & 1.06 \\
\hline Borderline & 30 & 6.36 & 7.42 \\
\hline Low average & 66 & 13.98 & 21.94 \\
\hline Average & 276 & 58.47 & 79.87 \\
\hline High average & 30 & 12.71 & 92.58 \\
\hline Superior & 31 & 6.57 & 99.15 \\
\hline Very superior & 4 & 0.85 & 100.0 \\
\hline \multicolumn{4}{|l|}{ Cognitive } \\
\hline Extreme low & 5 & 1.07 & 1.07 \\
\hline Borderline & 4 & 0.85 & 192 \\
\hline Low average & 36 & 7.68 & 9.59 \\
\hline Average & 300 & 63.97 & 73.56 \\
\hline High average & 105 & 22.39 & 95.95 \\
\hline Superior & 17 & 3.62 & 99.47 \\
\hline Very superior & 2 & 0.42 & 100.0 \\
\hline
\end{tabular}

Trends Psychiatry Psychother. 2018;40(3) - 235 
related to higher scores on language and cognition. We found a low prevalence of significant delay in development at 6 months of age in this birth cohort in the outskirts of São Paulo. It is important to highlight that differences in language and cognition development were observed very early in the life of those infants, taking into account that they had not learned to talk yet (Bayley scales evaluate preverbal communication). The findings of this study are in agreement with results of other studies that have shown the contribution of SES to cognitive performance in different age groups. $6,8,12,13,21,23,24,28,56-61$
It has been found that children from families with lower incomes show an approximate $50 \%$ probability of a developmental delay, even after adjusting for maternal education. Possibly, children from higher SES have a variety of beneficial opportunities in the first year of life, with a positive effect on development. 4,27,58 Studies addressing the association between SES and brain structure and function development have shown that early experiences have an expressive effect, even in the first few months of life. $8,25,58,61,62$ Also, investigations relating SES and cognitive development/performance have shown that poverty

Table 2 - Median developmental scores according to sociodemographic characteristics of a birth cohort in the city of São Paulo, Brazil.

\begin{tabular}{|c|c|c|c|c|c|c|c|}
\hline Strata & N*(\%) & Motor & IQR & Language & IQR & Cognition & IQR \\
\hline \multicolumn{8}{|l|}{ SES } \\
\hline High ( $A+B$ status $)$ & $70(17.3)$ & 100 & $91-107$ & 103 & $94-109$ & 105 & $95-110$ \\
\hline Medium (C status) & $275(67.9)$ & 100 & $91-110$ & 100 & $91-109$ & 105 & $95-105$ \\
\hline Low (D+E status) & $60(14.8)$ & 95.5 & $85.75-107$ & 97 & $89-103$ & 100 & $95-105$ \\
\hline \multicolumn{8}{|l|}{ Paternal occupation } \\
\hline Non manual, qualified & $63(16.5)$ & 97 & $88-107$ & 98 & $91-109$ & 100 & $95-110$ \\
\hline Semi-qualified & $70(18.4)$ & 103 & $91-112$ & 100 & $93.25-112$ & 105 & $100-110$ \\
\hline Unskilled manual & $248(65.1)$ & 97 & $91-107$ & 100 & $91-106$ & 100 & $95-110$ \\
\hline \multicolumn{8}{|l|}{ Maternal education (years) } \\
\hline$\geq 11$ & $200(40.8)$ & 97 & $88-107$ & 103 & $91-109$ & 105 & $95-110$ \\
\hline $9-10$ & $194(39.6)$ & 97 & $88-107$ & 98 & $89-106$ & 100 & $95-110$ \\
\hline $5-8$ & $87(17.8)$ & 97 & $88-107$ & 97 & $91-103$ & 100 & $95-105$ \\
\hline $0-4$ & $9(1.8)$ & 91 & 83.5-98.5 & 97 & $84.5-107.5$ & 95 & 90-105 \\
\hline
\end{tabular}

IQR = interquartile range; SES = socioeconomic status.

* Discrepancy due to missing information.

Table 3 - Bootstrapping quantile regression of the association between sociodemographic characteristics and infant development in a birth cohort in the city of São Paulo, Brazil

\begin{tabular}{lcccc}
\hline & Coef & $\mathbf{p}$ & \multicolumn{2}{c}{$\mathbf{9 5 \%} \mathbf{C I}$} \\
\hline Motor & & & -5.79 & -0.21 \\
$\quad$ SES & -3.00 & 0.035 & -3.40 & 0.40 \\
Paternal occupation & .50 & 0.121 & -2.28 & 2.28 \\
$\quad$ Maternal education & 0.00 & 1 & & \\
& & & & \\
Language & & & -5.73 & -0.27 \\
SES & -3.00 & 0.031 & -2.62 & 2.62 \\
$\quad$ Paternal occupation & 0.00 & 1 & -5.01 & -0.99 \\
Maternal education & -3.00 & 0.003 & & \\
& & & & \\
Cognition & & & -5.95 & 0.95 \\
$\quad$ SES & -2.50 & 0.155 & -5.10 & 0.10 \\
$\quad$ Paternal occupation & -2.50 & 0.059 & -6.33 & -0.34 \\
$\quad$ Maternal education & -3.33 & 0.029 & & \\
\hline
\end{tabular}

$95 \% \mathrm{CI}=95 \%$ confidence interval; Coef $=$ median effect on the dependent variable, conditional on the values of the independent variable; SES = socioeconomic status. 
in the first years of life affects infant development ${ }^{26,61}$ and that these effects can be seen later in life through adulthood. ${ }^{29,30}$ These long-lasting effects are probably reflecting epigenetic mechanisms. ${ }^{63}$ The expression of genes in an organism can be influenced by the environment, given that the environment-genotype correlation resulting from each individual's experiences is correlated with genetic propensities. For example, findings from a recent study show significant genetic influences on the association between family socioeconomic factors and intelligence when the child is 2-7 years old. 64

Verbal language is the set of processes that allows us to use a code or a conventional system to represent concepts or communicate them. ${ }^{65}$ Verbal language also requires that the child has developed basic skills such as motor integrity, sensory-perceptual and emotional mastery of language and the capacity of symbolization. ${ }^{66}$

We found that the lower the SES and maternal education, the lower the scores of infant language development; this result is consistent with several studies that have looked at child development and family SES. ${ }^{67}$ Predictors of social status vulnerability have been associated with deficits in child development, ${ }^{4,49}$ with children from low SES showing a slower rate of expressive language development compared with children from high SES before 3 years of age. ${ }^{8,58,61}$ Similarly, maternal education was associated with delayed language development. The higher the education status of mothers, the greater their knowledge of child development. Studies show that higher maternal educational level is associated with a greater quality of the interaction between mothers and their premature babies at 3 years of age. ${ }^{68,69}$ Mothers with higher education levels appear to be more likely to read and expose their children to language stimuli than mothers with lower educational levels. ${ }^{70,71}$ Exposure to language stimuli in the home appears to be quite relevant to the child's school performance later in life and to the development of phonological awareness, as well as the ability to distinguish between different sounds. $36,38,45,70$

In addition to cognitive and language measures, our results showed an association between maternal education and motor scores. The acquisition of motor skills is constant in the first years of life; only the pace of this course varies from one child to another. Previous studies point to different patterns of motor skill development according to child age and not significantly related to environmental factors (e.g., infections, trauma and hospital stay). Also, motor skills allow the acquisition of other abilities, cognitive and language- related, thus allowing to expand the understanding and progressive organization of the environment. ${ }^{72,73}$

Our study indicates different contributions of the diverse SES factors investigated. Even though researchers have frequently described SES as an index composed of a combination of family income and parental education and occupation, ${ }^{74}$ others suggest that these factors may have specific, independent contributions to development. ${ }^{75,76}$ It has been hypothesized that higher income may enable families to provide healthier and more stimulating home environments, as a result of the availability of high-quality resources and learning materials. ${ }^{75,76}$ Conversely, parental education may be more strongly associated with parenting habits and cognitive stimulation at the home..$^{75-78}$ We did not find a significant association between paternal occupation and infant performance, although we did observe a trend ( $p=0.059$ ). In fact, previous studies suggested that the effects of parental occupation on child development outcomes is indirect, i.e., mediated by educational level. ${ }^{79}$

There is evidence suggesting that the earlier the delay in development is diagnosed and appropriate interventions provided, the lesser the impact of these problems in the future life of the child. ${ }^{80,81}$ The importance of early identification of the most vulnerable groups is essential to minimize recurring negative effects. However, it is important to note that early identification of developmental problems is a difficult task for primary care professionals, requiring training and liaison with specialists. This study is relevant to the literature on child development, as it establishes parameters on developmental delays and on psychosocial and environmental effects on the first years of life and development, which are rare in Brazil. In the last decades, cognitive neuroscience and other areas such as child psychiatry have acknowledged the importance of research in this area. ${ }^{47}$ However, studies with children living in poverty are very hard to carry on, especially due to the difficult access to these populations. In this sense, this study represents a very unique investigation of infant development in a disadvantaged neighborhood in Brazil, taking into account the stressful conditions in which the families lived (poverty, violence, etc.). It was essential that the psychologists were able to maintain a trustful relationship with the families to get trustworthy and reliable information and ensure the assessment of child development through a wellestablished approach.

This study is not without limitations. First, our design was cross-sectional, so we cannot interpret the findings as casual, given that such interpretations are better addressed with longitudinal designs. ${ }^{82}$ Also, in 
this study, the analysis were not controlled for possible confounding variables - e.g., nutritional status, obstetric complications, maternal age, etc.

Notwithstanding, the findings from this study highlight the importance of greater investment in early childhood development care. Prevention programs to decrease risk factors, stimulate early childhood development and strengthen primary health care through home visits, whether by professionals or community workers, to families of greater social vulnerability, are of critical importance to solidify the education and care of children. Implementation projects to promote education and care of at-risk families are very important and necessary, especially in developing countries. Spending on assistance programs for families as a means of prevention is an investment in the future, with potential long-term economic compensation by preventing further damage to society. Equally important is the implementation of projects to promote the education and care of vulnerable families, especially in developing countries. Investments like these in the future become a source of economy for the country, as parental guidance and education are protective factors in society by way of fostering conditions for these children to become resilient.

\section{Conclusion}

The developing brain is strongly influenced by the children's experiences in the first years of life, which means that children are particularly vulnerable to environmental adversity. Our findings indicate that SES effects are detectable very early in infancy. This has implications for the timing of both screening and intervention efforts to help children overcome the consequences of living in poverty. Our results highlight the importance of early and appropriate monitoring of children living in adverse environments. From a different point of view, however, as experiences have such an influence on child development in the first years of life, infancy should also represent an important target time window for parents, communities and policymakers to create healthy and stimulating environments and help children develop their full potential.

\section{Acknowledgements}

This study was funded by Coordenação de Aperfeiçoamento de Pessoal de Nível Superior (CAPES) and Instituto Nacional de Psiquiatria do Desenvolvimento para Crianças e Adolescentes.

\section{Disclosure}

Luis Augusto Rohde has received grant or research support from, served as a consultant to, and served on the speakers' bureau of Eli Lilly and Co., Janssen, Novartis and Shire. The ADHD and Juvenile Bipolar Disorder Outpatient Programs chaired by him have received unrestricted educational and research support from the following pharmaceutical companies: Eli Lilly and Co., Janssen, Novartis, and Shire. He has received travel grants from Shire to take part in the 2014 APA and 2015 WFADHD congresses. He has received royalties from Artmed Editora and Oxford University Press. No conflicts of interest declared by the other authors concerning the publication of this article.

\section{References}

1. Steinmetz N. The development of children and the health of societies. Paediatr Child Health. 2010;15:11-2.

2. Hackman DA, Farah MJ, Meaney MJ. Socioeconomic status and the brain: mechanistic insights from human and animal research. Nat Rev Neurosci. 2010;11:651-9.

3. Handal AJ, Lozoff B, Breilh J, Harlow SD. Sociodemographic and nutritional correlates of neurobehavioral development: a study of young children in a rural region of Ecuador. Rev Panam Salud Publica. 2007;21:292-300.

4. Halpern R, Giugliani ERJ, Victora CG, Barros FC, Horta BL. Fatores de risco para suspeita de atraso no desenvolvimento neuropsicomotor aos 12 meses de vida. Rev Chil Pediatr. 2002;73:529-39.

5. Andraca I de, Pino P, La Parra A de, Rivera F, Castillo M. Factores de riesgo para el desarrollo psicomotor en lactantes nacidos en óptimas condiciones biológicas. Rev Saude Publica. 1998;32:13847.

6. Noble KG, Farah MJ. Neurocognitive consequences of socioeconomic disparities: The intersection of cognitive neuroscience and public health. Dev Sci. 2013;16:639-40.

7. Noble KG, Houston SM, Brito NH, Bartsch H, Kan E, Kuperman $\mathrm{JM}$, et al. Family income, parental education and brain structure in children and adolescents. Nat Neurosci. 2015;18:773-8.

8. Noble KG, Engelhardt LE, Brito NH, Mack LJ, Nail EJ, Angal J, et al. Socioeconomic disparities in neurocognitive development in the first two years of life. Dev Psychobiol. 2015; 57:535-51.

9. Rosa Neto F, Caon G, Bissani C, Silva C, Silva MSE. Psychomotor characteristics of high neurological risk children from a follow-up program. Rev Bras Med. 2010;11:52-8.

10. Brasil, Ministério da Saúde. Saúde da criança: acompanhamento do crescimento e desenvolvimento infantil. Brasília: Ministério da Saúde; 2002. Série Cadernos de Atenção Básica, nº 11.

11. Miranda LP, Resegue R, Figueiras AC de M. A criança e o adolescente com problemas do desenvolvimento no ambulatório de pediatria. J Pediatr. 2003;79:S33-42.

12. Piccolo LR, Falceto OG, Fernandes $C L$, Levandowski DC, GrassiOliveira R, Salles JF. Variáveis psicossociais e desempenho em leitura de crianças de baixo nível socioeconômico. Psicol Teor Pesq. 2012:28:389-98.

13. Piccolo LR, Fonseca RP, Arteche AX, Grassi-Oliveira R, Salles JF. Influence of family socioeconomic status on IQ, language, memory and executive functions of children. Psicol Reflex Crit. 2016;29:23.

14. Marturano EM. Recursos no ambiente familiar e dificuldades de aprendizagem na escola. Psicol Teor Pesq. 1999;15:135-42.

15. Ardila A, Rosselli M, Matute $E$, Guajardo $S$. The influence of the parents' educational level on the development of executive functions. Dev Neuropsychol. 2005;28:539-60.

16. Rosselli $M$, Ardila A. The impact of culture and education on nonverbal neuropsychological measurements: A critical review. Brain Cogn. 2003;52:326-33. 
17. Feldman R, Eidelman AI. Biological and environmental initial conditions shape the trajectories of cognitive and social-emotional development across the first years of life. Dev Sci. 2009;12:194200.

18. Ermisch J, Francesconi M. The effect of parental employment on child schooling. J Appl Econom. 2013;28:796-822.

19. Caughy MO, Dipietro JA, Strobino DM, Santos LM, Santos CAS, Strina A, et al. Day-care participation as a protective factor in the cognitive development of low-income children. Child Dev. 1994;65:457.

20. Haggerty RJ, Sherrod LR, Gamezy N, Rutter M. Stress, risk and resilience in children and adolescents: process, mechanisms and interventions. New York: Cambridge University; 2000.

21. Hackman DA, Farah MJ. Socioeconomic status and the developing brain. Trends Cogn Sci. 2009;13:65-73.

22. Farah MJ, Betancourt L, Shera DM, Savage JH, Giannetta JM, Brodsky NL, et al. Environmental stimulation, parental nurturance and cognitive development in humans. Dev Sci. 2008;11:793801.

23. Noble KG, McCandliss BD, Farah MJ. Socioeconomic gradients predict individual differences in neurocognitive abilities. Dev Sci. 2007;10:464-80.

24. Noble KG, Wolmetz ME, Ochs LG, Farah MJ, McCandliss BD. Brainbehavior relationships in reading acquisition are modulated by socioeconomic factors. Dev Sci. 2006;9:642-54.

25. Brito $\mathrm{NH}$, Noble KG. Socioeconomic status and structural brain development. Front Neurosci. 2014;8:276.

26. Tomalski P, Moore DG, Ribeiro H, Axelsson EL, Murphy E, Karmiloff-Smith $A$, et al. Socioeconomic status and functional brain development - associations in early infancy. Dev Sci. 2013; 16:676-87

27. Hart B, Risley TR. Meaningful differences in the everyday experience of young American children. Baltimore: Brookes; 1995.

28. Melvin SA, Brito NH, Mack LJ, Engelhardt LE, Fifer WP, Elliott $\mathrm{AJ}$, et al. Home environment, but not socioeconomic status, is linked to differences in early phonetic perception ability. Infancy. 2017;22:42-55

29. Evans GW, Fuller-Rowell TE. Childhood poverty, chronic stress, and young adult working memory: the protective role of selfregulatory capacity. Dev Sci. 2013;16:688-96.

30. Evans GW, Schamberg MA. Childhood poverty, chronic stress, and adult working memory. Proc Natl Acad Sci U S A. 2009;106:65459.

31. Zorzi JL. Aspectos básicos para comprrensão, disgnóstico e prevenção dos distúrbios de linguagem na infância. Rev CEFAC. 2000;2:11-5.

32. Hoff E. Interpreting the early language trajectories of children from low-SES and language minority homes: Implications for closing achievement gaps. Dev Psychol. 2013;49:4-14.

33. Hoff $\mathrm{E}$. The specificity of environmental influence: socioeconomic status affects early vocabulary development via maternal speech. Child Dev. 2003;74:1368-78.

34. Hoff E. How social contexts support and shape language development? Dev Rev. 2006;26:55-88.

35. Hoff E, Tian C. Socioeconomic status and cultural influences on language. J Commun Disord. 2005;38:271-8.

36. Duursma E, Augustyn M, Zuckerman B. Reading aloud to children: the evidence. Arch Dis Child. 2008;93:554-7.

37. Foy JG, Mann V. Home literacy environment and phonological awareness in preschool children: differential effects for rhyme and phoneme awareness. Appl Psycholinguist. 2002;24:59-88.

38. Haney M, Hill J. Relationships between parent-teaching activities and emergent literacy in preschool children. Early Child Dev Care. 2004; 174:215-28

39. Senechal M, LeFevre J-A. Parental involvement in the development of children's reading skill: a five-year longitudinal study. Child Dev. 2002;73:445-60.

40. Raviv T, Kessenich M, Morrison FJ. A mediational model of the association between socioeconomic status and three-year-old language abilities: the role of parenting factors. Early Child Res Q. 2004;19:528-47.

41. Grieshaber S, Shield P, Luke A, Macdonald S. Family literacy practices and home literacy resources: an Australian pilot study. J Early Child Lit. 2011;12:113-38.

42. El Nokali NE, Bachman HJ, Votruba-Drzal E. Parent involvement and children's academic and social development in elementary school. Child Dev. 2010;81:988-1005.

43. Pampel FC, Krueger PM, Denney JT. Socioeconomic disparities in health behaviors. Annu Rev Sociol. 2010;36:349-70.
44. Brito NH, Fifer WP, Myers MM, Elliott AJ, Noble KG. Developmental cognitive neuroscience associations among family socioeconomic status, EEG power at birth, and cognitive skills during infancy. Dev Cogn Neurosci. 2016;19:144-51.

45. Halle T, Forry N, Hair E, Perper K, Wandner L, Wessel J, Vick J. Disparities in early learning and development: lessons from the Early Childhood Longitudinal Study--Birth Cohort (ECLS-B). Child Trends. 2009;43:345-57

46. Grantham-McGregor S, Cheung YB, Cueto S, Glewwe P, Richter L, Strupp B. Developmental potential in the first 5 years for children in developing countries. Lancet. 2007;369:60-70.

47. Collins PY, Patel V, Joestl SS, March D, Insel TR, Daar AS, et al. Grand challenges in global mental health. Nature. 2011;475:2730.

48. Ferraro AA, Rohde LA, Polanczyk GV, Argeu A, Miguel EC, Grisi SJFE, et al. The specific and combined role of domestic violence and mental health disorders during pregnancy on new-born health. BMC Pregnancy Childbirth. 2017;17:257.

49. Halpern R, Barros FC, Horta BL, Victora CG. Desenvolvimento neuropsicomotor aos 12 meses de idade em uma coorte de base populacional no Sul do Brasil: diferenciais conforme peso ao nascer e renda familiar. Cad Saude Publica. 1996;12:S73-8.

50. Miguel EC, Rohde LA. Novas ferramentas na compreensão do desenvolvimento infantil: a interação gene-ambiente e a conectividade neuronal [research project]. São Paulo: USP; 2008.

51. Bayley N. Bayley scales of infant development. 2nd ed. San Antonio: Psychological Corporation; 1993.

52. Madaschi CSPV, Madaschi V, Silvestre PC, Financeiro A. Medidas de avaliação do desenvolvimento infantil: uma revisão da literatura nos últimos 5 anos. Cad Dist Desenv. 2011;11:52-6.

53. Madaschi V, Mecca TP, Macedo EC, Paula CS, Madaschi V, Mecca TP, et al. Bayley-III Scales of Infant and Toddler Development: transcultural adaptation and psychometric properties. Paid. 2016;26:189-97.

54. Associação Brasileira de Empresas de Pesquisa (ABEP). Critério de Classificação Econômica Brasil [web site]. 2009. http://www. abep.org/criterio-brasil

55. Olsen J, Frische G. Social differences in reproductive health. Scand J Soc Med. 1993;21:90-7.

56. Brito NH, Piccolo LR, Noble KG. Associations between cortical thickness and neurocognitive skills during childhood vary by family socioeconomic factors for the Pediatric Imaging, Neurocognition, and Genetics Study. Brain Cog. 2017; 116:54-62.

57. Fernald LCH, Weber A, Galasso E, Ratsifandrihamanana L. Socioeconomic gradients and child development in a very low income population: evidence from Madagascar. Dev Sci. 2011;14:832-47.

58. Fernald A, Marchman VA, Weisleder A. SES differences in language processing skill and vocabulary are evident at 18 months. Dev Sci. 2013;16:234-48.

59. Lipina S, Segretin S, Hermida J, Prats L, Fracchia C, Camelo JL, et al. Linking childhood poverty and cognition: Environmental mediators of non-verbal executive control in an Argentine sample. Dev Sci. 2013;16:697-707.

60. Noble KG, Tottenham N, Casey BJ. Neuroscience perspectives on disparities in school readiness and cognitive achievement. Future Child. 2005; 15:71-89.

61. Pungello EP, Iruka IU, Dotterer AM, Mills-Koonce R, Reznick JS. The effects of socioeconomic status, race, and parenting on language development in early childhood. Dev Psychol. 2009;45:544-57.

62. Johnson SB, Riis JL, Noble KG. State of the art review: poverty and the developing brain. Pediatrics. 2016;137:1-10.

63. Graff J, Mansuy IM. Epigenetic codes in cognition and behaviour. Behav Brain Res. 2008;192:70-87.

64. Trzaskowski M, Harlaar N, Arden R, Krapohl E, Rimfeld K, McMillan $A$, et al. Genetic influence on family socioeconomic status and children's intelligence. Intelligence. 2014;42:83-8.

65. Castaño J. Bases neurobiológicas del language y sus alteraciones. Rev Neurol. 2003;36:781-5.

66. Schirmer CR, Fontoura DR, Nunes ML. Distúrbios da aquisição da linguagem e da aprendizagem. J Pediatr. 2004;80:95-103.

67. Eickmann SH, de Lira PIC, Lima M de C, Coutinho SB, Teixeira $M$ de LPD, Ashworth A. Breast feeding and mental and motor development at 12 months in a low-income population in northeast Brazil. Paediatr Perinat Epidemiol. 2007;21:129-37.

68. Biscegli TS, Polis LB, Santos LM dos, Vicentin M. Avaliação do estado nutricional e do desenvolvimento neuropsicomotor em crianças freqüentadoras de creche. Rev Paul Pediatr. 2007;25:33742. 
69. Cho J, Holditch-Davis D, Belyea M. Gender, ethnicity, and the interactions of prematurely born children and their mothers. ] Pediatr Nurs. 2004;19:163-75.

70. Kuo AA, Franke TM, Regalado M, Halfon N. Parent report of reading to young children. Pediatrics. 2004;113(6 Suppl):1944-51.

71. Skibbe LE, Justice LM, Zucker TA, McGinty AS. Relations among maternal literacy beliefs, home literacy practices, and the emergent literacy skills of preschoolers with specific language impairment. Early Educ Dev. 2008;19:68-88.

72. Perez-Escamilla R, Pollitt E. Causes and consequences of intrauterine growth retardation in Latin America. Bull Pan Am Health Organ. 1992;26:128-47.

73. Gajewska E, Baraska E, Sobieska M, Moczko J. Motor performance in the third, not the second month, predicts further motor development. J Mot Behav. 2015;47:246-55.

74. McLoyd VC. Socioeconomic disadvantage and child development. Am Psychol. 1998;53:185-204.

75. Duncan GJ, Magnuson K. Socioeconomic status and cognitive functioning: Moving from correlation to causation. Wiley Interdiscip Rev Cogn Sci. 2012;3:377-86.

76. Duncan GJ, Magnuson K, Votruba-Drzal E. Boosting family income to promote child development. Futur Child. 2014;24:99-120.

77. Fletcher J, Frisvold D. Higher education and health investments: does more schooling affect preventive health care use? J Hum Cap. 2009;3:144-76.
78. Chou S-Y, Liu J-T, Grossman M, Joyce T. Parental education and child health: evidence from a natural experiment in Taiwan. Am Econ J Appl Econ. 2010;2:33-61.

79. Dubow EF, Boxer P, Huesmann LR. Long-term effects of parents' education on children's educational and occupational success: mediation by family interactions, child aggression, and teenage aspirations. NIH Public Access; 2009;55:224-49.

80. Dworkin PH. British and American recommendations for developmental monitoring: the role of surveillance. Pediatrics. 1989;84:1000-10

81. Valman HB. Development surveillance at 6 weeks. $\mathrm{Br}$ Med J. 1980;280:1000-2.

82. Kraemer HC, Yesavage JA, Taylor JL, Kupfer D. How can we learn about developmental processes from cross-sectional studies, or can we? Am J Psychiatry. 2000;157:163-71.

\section{Correspondence:}

Patricia Tella

Departamento de Pediatria, Faculdade de Medicina, Universidade de São Paulo

Av. Dr. Enéas de Carvalho Aguiar, 647

05403-000 - São Paulo, SP - Brazil

Tel.: +551 2661-8805

E-mail: patriciatella@gmail.com 